\title{
44. DATA REPORT: DISTRIBUTION OF PLEISTOCENE BENTHIC FORAMINIFERS FROM THE EASTERN EQUATORIAL ATLANTIC OCEAN ${ }^{1}$
}

\author{
Alain Lévy², Robert Mathieu ${ }^{3}$, Armelle Poignant ${ }^{2}$, and Marie Rosset-Moulinier ${ }^{4}$
}

\begin{abstract}
Pleistocene benthic foraminifers recovered from four sites during Ocean Drilling Program Leg 159, located in the eastern equatorial Atlantic Ocean off the Côte d'Ivoire-Ghana, have been studied. Four different assemblages have been identified, each representing various depths and water masses.
\end{abstract}

\section{INTRODUCTION}

For this study, four sites from the Ocean Drilling Program Leg 159, located on the Côte d'Ivoire-Ghana Transform Continental Margin in the eastern equatorial Atlantic Ocean, were examined (Fig. 1):

Site 959 , located in $2100 \mathrm{~m}$ water depth on a small plateau that extends just north of the Côte d'Ivoire-Ghana marginal ridge on the southern shoulder of the deep Ivorian Basin;

Site 960, located $3 \mathrm{mi}$ south of Site 959 in $2061 \mathrm{~m}$ water depth;

Site 961 , located in $3303 \mathrm{~m}$ water depth at the bottom of the Côte d'Ivoire-Ghana marginal ridge; and

Site 962 , located in $4650 \mathrm{~m}$ water depth on a small topographic bench southwest of the Côte d'Ivoire-Ghana marginal ridge's southern slope.

The uppermost parts of Sites 959, 960, and 961 (Shipboard Scientific Party, 1996a, 1996b, 1996c) are of Pleistocene age and consist of predominantly calcareous sediments with pyrite and organic matter. The uppermost part of Site 962 is of late Pleistocene age and consists of silty clays. It is located near the depth of the foraminifer lysocline. At Site 959, planktonic foraminifer data indicate an apparently continuous sequence from the middle Miocene M3 to the Holocene. Site 960 provides a nearly complete record of the Pliocene, but the Pleistocene sequence is disturbed. A discontinuous sequence from the Pleistocene to the upper Paleocene was identified at Site 961. At Site 962, a Holocene to late Pliocene assemblage is dominated by dissolution-resistant planktonic foraminifer taxa (Shipboard Scientific Party, 1996d).

We have studied the Pleistocene benthic foraminifers.

\section{METHODS AND MATERIALS}

At Hole 959A, 13 Pleistocene samples have been examined: four from Hole 960C, three from Hole 961A - in which the Pleistocene sequence is very reduced - and 10 very poor or azoic samples from Hole 962B, which represents a deep sequence.

${ }^{1}$ Mascle, J., Lohmann, G.P., and Moullade, M. (Eds.), 1998. Proc. ODP, Sci. Results, 159: College Station, TX (Ocean Drilling Program).

${ }^{2}$ Laboratoire de Stratigraphie, Université Pierre et Marie Curie, 4, place Jussieu, 75252 Paris Cedex 05, France. robmat@ccr.jussieu.fr

${ }^{3}$ Laboratoire de Micropaléontologie, Case 104, Université Pierre et Marie Curie, 4, place Jussieu, 75252 Paris Cedex 05, France.

${ }^{4}$ Institut de Biogéochimie Marine, Ecole Normale Supérieure, 1, rue Maurice Arnoux, 92120 Montrouge, France.
The samples were sieved on a $0.05-\mathrm{mm}$ screen and counted to obtain about 150 specimens. For the least rich samples, foraminifers were extracted with $\mathrm{CCl}_{4}$.

The benthic foraminifers are listed in Table 1, and some of them are illustrated with SEM micrographs (PI. 1).

\section{COMPOSITION OF THE ASSEMBLAGES}

We have observed 90 species: three Textulariina, nine Miliolina and 80 Lagenina and Rotaliina. The most frequently encountered species at the four sites were (in alphabetical order)

Bulimina rostrata,

Cassidulina laevigata,

Epistominella exigua,

Fontbotia wuellerstorfi,

Hoeglundina elegans,

Melonis parkerae,

Stilostomella adolphina,

Uvigerina hispida, and

Uvigerina peregrina.

The most abundant species were

Bulimina aculeata

Cassidulina laevigata,

Epistominella exigua,

Eponides tenera,

Melonis parkerae,

Uvigerina hispida, and

Uvigerina peregrina.

Overall, the most abundant species from the four sites was Epistominella exigua.

Rare species encountered, represented in only one or two sites, were

Allomorphina trigona,

Bolivina pseudoplicata,

Bulimina aculeata,

Bulimina clava,

Bulimina exilis,

Bulimina striata subsp mexicana,

Cancris oblongus,

Cassidulina crassa,

Cassidulinoides parkerianus,

Ceratobulimina pacifica, 
Figure 1. Locations of drilling sites on the Côte d'Ivoire-Ghana Transform Margin and surroundings (bathymetry is in meters), after Benkhelil et al. (1995).

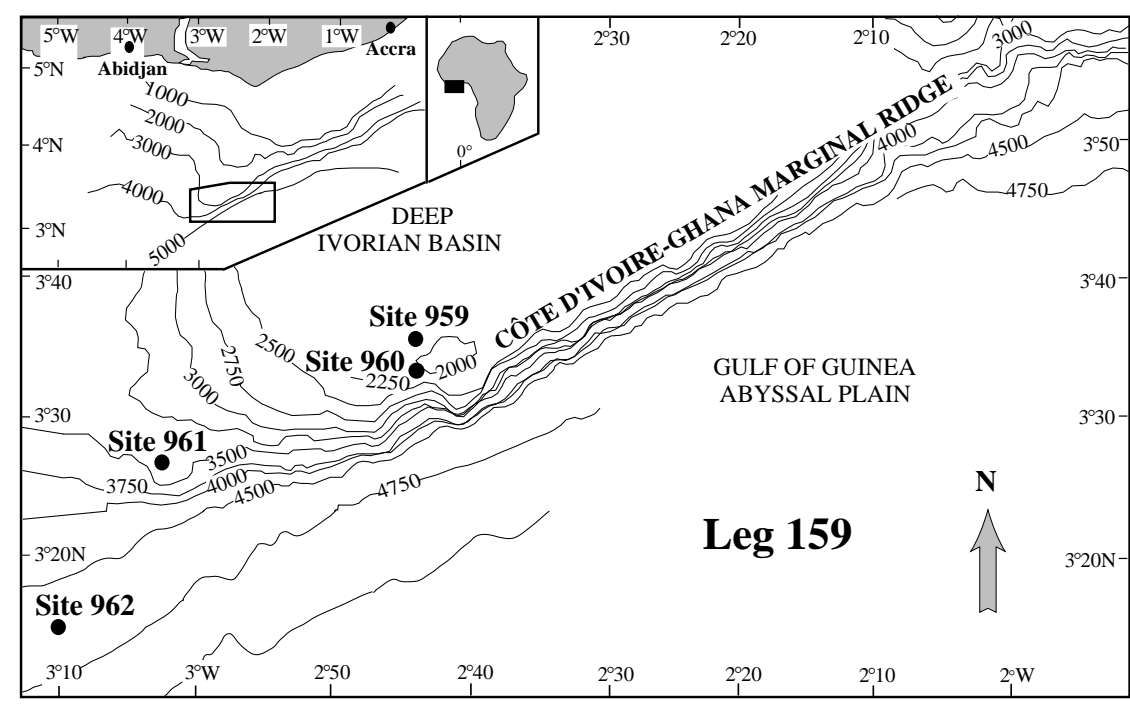

2. Cassidulina laevigata and Uvigerina peregrina assemblage. $C$. laevigata is predominant at Sites 959 and 960 . It is associated with $B$. marginata, B. rostrata, $F$. wuellerstorfi, $G$. subglobosa, M. parkerae, Pullenia bulloides, Pyrgo murrhina, and $U$. hispida.

This group is indicative of a rather large range of depths (Murray, 1991). Both species, C. laevigata and U. peregrina, are found together (Murray, 1991).

3. Epistominella exigua assemblage. It is most predominant at Site 959 (7.9 to $12.5 \mathrm{~m}$ depth), then in Hole 960C (as deep as 0.49 to $15.7 \mathrm{~m}$ ), and at Site 961 (at $1.5 \mathrm{~m}$ depth). E. exigua is associated with Heterolepa sp., Hoeglundina elegans, Cassidulina laevigata, Melonis parkerae, Stilostomella adolphina, Uvigerina hispida, U. peregrina.

According to Murray (1991), this assemblage is indicative of a salinity lower than $35 \%$ and a temperature of $10^{\circ} \mathrm{C}$; this assemblage is related to North East Atlantic Deep Water (Worthington 1976) and was observed by Schnitker (1974) and Weston and Murray (1984). Epistominella exigua is often found in the "fluffy layer" which represents the remains of phytoplankton blooms on the sediment surface (Gooday, 1988 and Gooday et al., 1992, in Struck, 1995; Murray, 1991)

4. Eponides tenera assemblage. It is predominant at Site 959 (from 11 to $18.5 \mathrm{~m}$ depth). E. tenera is associated with Bulimina rostrata, Cassidulina laevigata, Cibicidoides mundulus, Gyroidinoides soldanii, Melonis parkerae, Stilostomella adolphina, Uvigerina hispida, and U. peregrina.

This assemblage is characteristic of cold waters and well known in the arctic seas (Murray, 1991).

Epistominella exigua, which is the most abundant species even at the foraminifer lysocline level, is a dissolution-resistant benthic species (Lévy et al., 1982). The scarcity of agglutinated specimens at depths down to $4650 \mathrm{~m}$ is very surprising. Agglutinated foraminifers are sometimes highly frequent in bathyal deposits (Brady, 1884; Lévy et al., 1982). On the contrary, Van Leeuwen (1989) noted the low and variable preservability of this group in the Angola basin.

Benthic foraminifers record, in their species composition, the properties of the water masses (Schnitker, 1980, Ruddiman and Jan- 
Table 1. Abundance counts of Pleistocene benthic foraminifers, Holes 959A, 960C, 961A, and 962B.

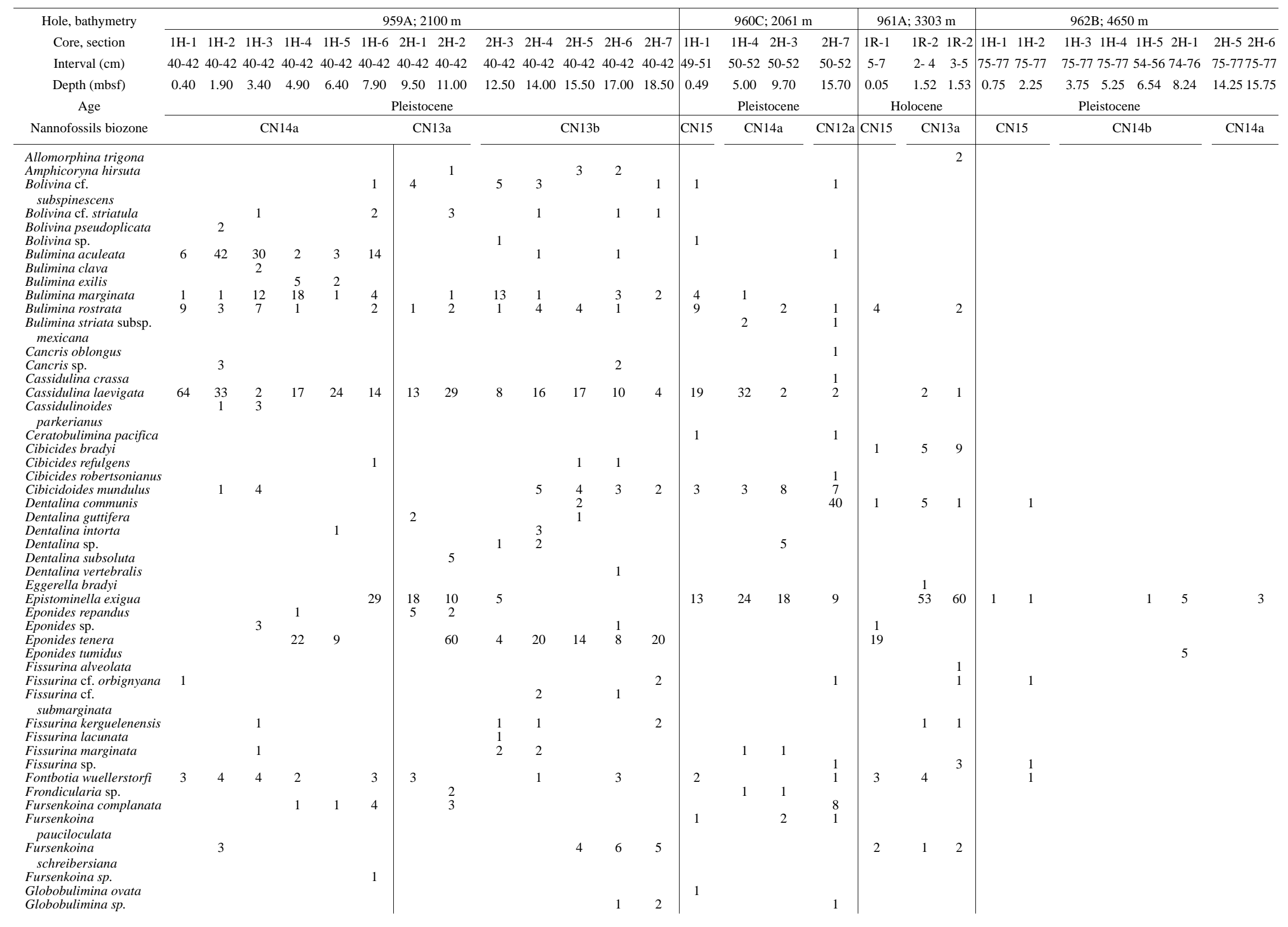


Table 1 (continued).

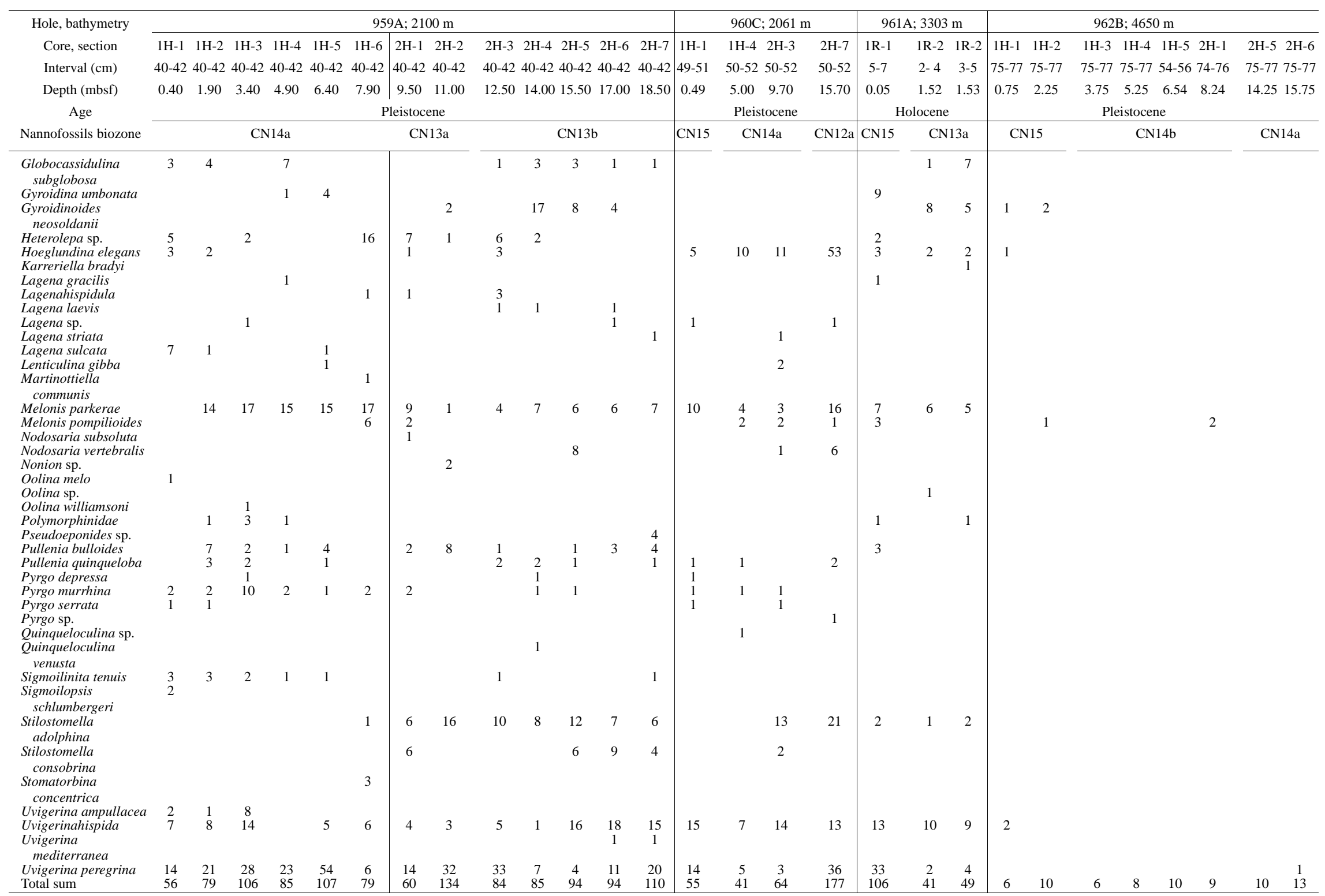


ecek, 1989). All the species belong to the typical fauna of the slope of the Atlantic seaboard of Europe and Africa (Douglas and Woodruff, 1981; Murray, 1991). Moreover, the assemblage with Globocassidulina subglobosa, Fontbotia wuellerstorfi, Hoeglundina elegans, and Uvigerina peregrina is considered by Schnitker (1974) and Weston and Murray (1984) to be typical of the North Atlantic Deep Water (NADW). Schnitker (1980), in his study of the Quaternary deep-sea benthic foraminifers, the assemblage characterized by $F$. wuellerstorfi and Epistominella exigua occurs in samples from $\mathrm{NADW}$, and the assemblage dominated by $U$. peregrina occurs in conjunction with relatively warm and saline water, which is in large part of Mediterranean origin.

\section{CONCLUSION}

In spite of the quantitative homogeneity of the microfaunal assemblages, the quantitative analysis shows the existence of four main assemblages.

The first two assemblages, with Bulimina aculeata, Cassidulina laevigata and Uvigerina peregrina, characterize the deep-sea water masses of the ocean (Murray, 1991).

The Epistominella exigua assemblage is related to the NADW, suggesting a temperature $>2^{\circ} \mathrm{C}$ and a salinity of $\sim 34^{\circ} 9$. This association is located in the lower part of Hole 959A (CN 14a and CN 13a).

The last assemblage, which contains Eponides tenera, confirms the cold character inferred from the previous association.

The upper part of Site 959 (CN 14a) shows a temperature greater than the one of the lower part, whereas Sites 960, 961, and 962 do not show any noticeable variations.

\section{REFERENCES}

Benkhelil, J., and l'Équipe Scientifique Embarquée, 1995. ODP Leg 159: la marge transformante de Côte d'Ivoire-Ghana (Atlantique équatorial). Geochronique, 56:8-9.

Berggren, W.A., and Haq, B.U., 1976. The Andalusian stage (late Miocene): biostratigraphy, biochronology and paleoecology. Palaeogeogr., Palaeoclimatol. Palaeoecol., 20:67-129.

Brady, H.B., 1884. Report on the Foraminifera dredged by H.M.S. Challenger, during the years 1873-1876. Rep. Sci. Results Challenger Exped., Zool., 9:1-814.
Douglas, R.G., and Woodruff, F., 1981. Deep-sea benthic foraminifera. In Emiliani, C. (Ed.), The Sea (Vol. 7): New York (Wiley-Interscience), $1233-1327$.

Lévy, A., Mathieu, R., Poignant, A., Rosset-Moulinier, M., and Rouvillois, A., 1982. Foraminifères benthiques actuels de sédiments profonds du golfe de Guinée. Cah. Micropaleontol., 2:123-133.

Murray, J.W., 1991. Ecology and Palaeoecology of Benthic Foraminifera: London (Longman).

Ruddiman, W.F., and Janecek, T.R., 1989. Pliocene-Pleistocene biogenic and terrigenous fluxes at equatorial Atlantic Sites 662, 663, and 664. In Ruddiman, W., Sarnthein, M., et al., Proc. ODP, Sci. Results, 108: College Station, TX (Ocean Drilling Program), 211-240.

Schnitker, D., 1974. West Atlantic abyssal circulation during the past 120,000 years. Nature, 248:385-387.

, 1980. Quaternary deep sea benthic foraminifers and bottom water masses. Annu. Rev. Earth Planet. Sci., 8:343-370.

Shipboard Scientific Party, 1996a. Site 959. In Mascle, J., Lohmann, G.P., Clift, P.D., et al., Proc. ODP, Init. Repts., 159: College Station, TX (Ocean Drilling Program), 65-150.

1996b. Site 960. In Mascle, J., Lohmann, G.P., Clift, P.D., et al., Proc. ODP, Init. Repts., 159: College Station, TX (Ocean Drilling Program), 151-215.

, 1996c. Site 961. In Mascle, J., Lohmann, G.P., Clift, P.D., et al., Proc. ODP, Init. Repts., 159: College Station, TX (Ocean Drilling Program), 217-249.

1996d. Site 962. In Mascle, J., Lohmann, G.P., Clift, P.D., et al., Proc. ODP, Init. Repts., 159: College Station, TX (Ocean Drilling Program), 251-294.

Struck, U., 1995. Stepwise postglacial migration of benthic foraminifera into the abyss northeastern Norwegian Sea. Mar. Micropaleontol., 26:207213.

van Leeuwen, R.J.W., 1989. Sea-floor distribution and Late Quaternary faunal patterns of planktonic and benthic foraminifers in the Angola Basin. Utrecht Micropaleontol. Bull., 38:1-287.

Weston, J.F., and Murray, J.W., 1984. Benthic foraminifera as deep-sea water-mass indicators. In Oertli, H.J. (Ed), Benthos '83, 605-10.

Worthington, L.V., 1976. On the North Atlantic Circulation: Baltimore (John Hopkins Univ. Press).

Date of initial receipt: 9 September 1996

Date of acceptance: 11 June 1997

Ms 159SR-020 


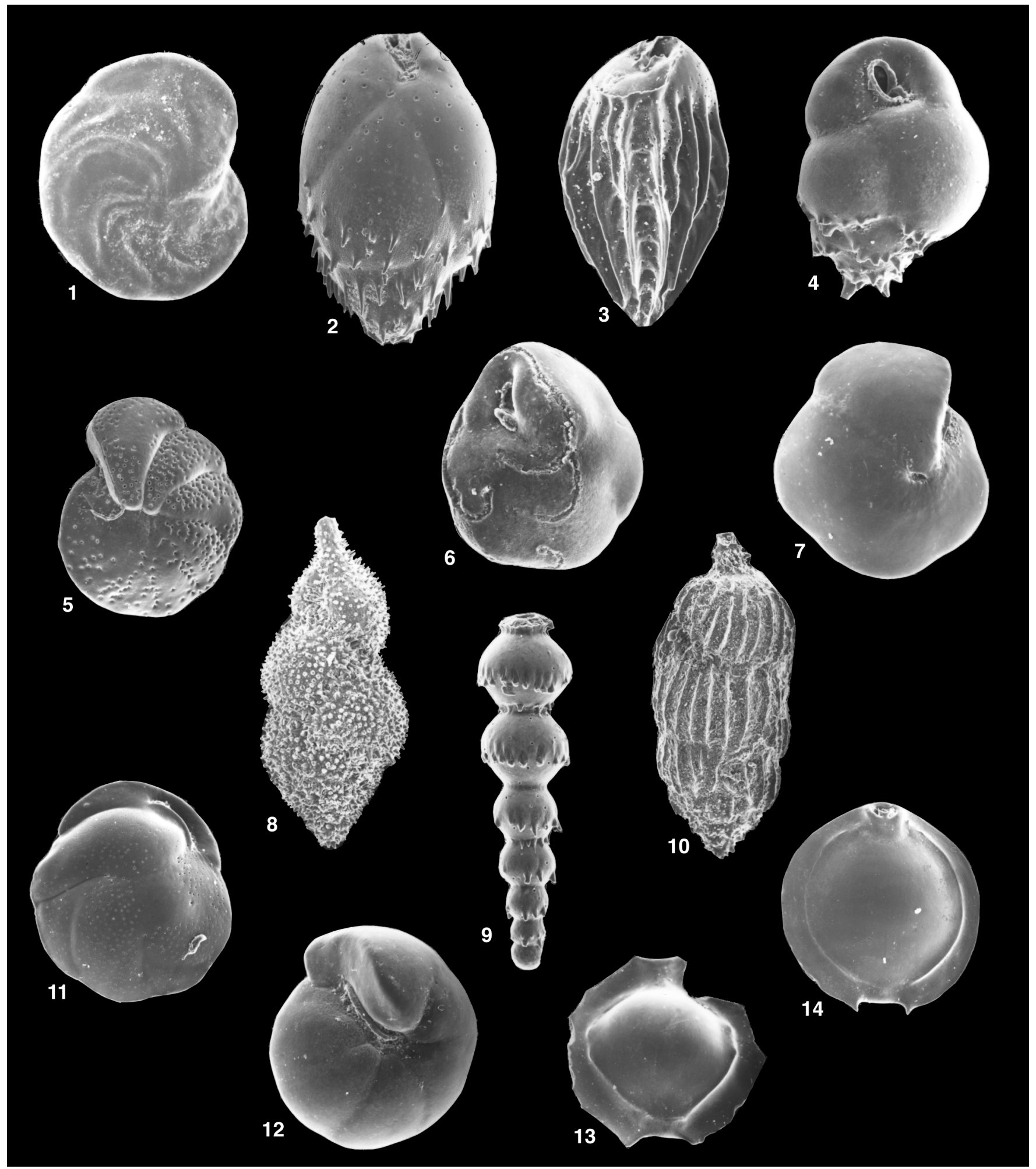

Plate 1. SEM pictures of benthic foraminifers. 1. Fontbotia wuellerstorfi (Schwager), Sample 159-959A-1H-2, 40-42 cm, 80×. 2. Bulimina aculeata d'Orbigny, Sample 159-959A-1H-2, 40-42 cm, 90×. 3. Bulimina rostrata Brady, Sample 159-959A-1H-4, 40-42 cm, 115×. 4. Bulimina marginata d'Orbigny, Sample 159959A-1H-4, 40-42 cm, 135×. 5. Cibicidoides mundulus (Brady), 159-959A-2H-4, 40-42 cm, 35×. 6. Epistominella exigua (Brady), 159-959A-2H-2, 40-42 $\mathrm{cm}, 185 \times$. 7. Epistominella tenera (Brady), Sample 159-959A-2H-2, 40-42 cm, 90×. 8. Uvigerina hispida Schwager, Sample 159-959A-2H-2, 40-42 cm, 80X. 9. Stilostomella adolphina (d'Orbigny), Sample 159-959A-2H-2, 40-42 cm, 85×. 10. Uvigerina peregrina Cushman, Sample 159-959A-1H-5, 40-42 cm, 55×. 11. Cassidulina laevigata d'Orbigny, Sample 159-959A-1H-2, 40-42 cm, 110×. 12. Gyroidinoides neosoldanii (Brotzen), Sample 159-959A-2H-4, 40-42 cm, 100×. 13. Pyrgo serrata Bailey, Sample 159-959A-1H-3, 40-42 cm, 50×. 14. Pyrgo murrhina (Schwager), Sample 159-959A-1H-3, 40-42 cm, 50×. 